Joseph Jaconelli*

\title{
Constitutional Disqualification: A Critique of English and English-Derived Law
}

https://doi.org/10.1515/icl-2019-0056

Published online October 14, 2020

\begin{abstract}
Many modern constitutional systems, despite the prevalence of adult suffrage, forbid certain classes of person from participation in the most important aspects of the democratic process, whether by withholding the vote from them or by denying them the right to hold office. While the former has received a considerable amount of attention in the literature, the latter has been comparatively neglected. The aim of the article is to redress this imbalance. It starts by offering, quite generally, a taxonomy of such bans. It then appraises, with particular reference to the constitutions of the English-speaking world, some of the most common grounds for disqualifying persons from holding elective office and the various purposes that these might be thought to serve. A major theme is the question whether some grounds of disqualification, notwithstanding their long history, can be justified.
\end{abstract}

Keywords: bankruptcy, criminal offences, disqualification, offices of profit, separation of powers.

\section{Introduction}

In what circumstances, in a democracy, is it legitimate to bar a person from holding elective office? Should any grounds of disqualification merely replicate the conditions under which the vote may be withheld from a person? If not, should they be more stringent than those conditions? Or should they be less stringent? Should the grounds be set in law or should they be regulated by convention, allowing scope for a final decision by the electorate? The purpose of this article is to conduct a critical appraisal of some of the most frequently encountered bars to the holding of elective office in the English-speaking world and to question whether they are appropriate to modern conditions.

\footnotetext{
*Corresponding author: Joseph Jaconelli, Law School, University of Manchester, Manchester, UK, E-mail: joseph.jaconelli@hotmail.com. https://orcid.org/0000-0003-3755-5651
} 


\section{Qualification and Disqualification: Preliminary Observations}

Constitutions almost invariably stipulate personal qualifications for the holding of elective office. For example, the Constitution of the USA requires, inter alia, that the President be a natural born citizen and at least 35 years of age. Some, less usually, also set out conditions for the possession of the franchise. Such requirements may be classified, according to their nature, in various ways.

First, they will characteristically lay down relatively uncontroversial conditions such as a link of birth or nationality between a person and the polity in question. These could be viewed as seeking to assure a minimal association, or even a bond of loyalty, between the individual and the polity. In the case of office holders such a bond may be strengthened, or simply created, by an obligation on their part to take an oath before taking up their position. However, the terms of any oath that is to be sworn may create further problems in turn, as evidenced by several instances, both historical ${ }^{1}$ and contemporary. ${ }^{2}$

A second form of condition disqualifies a person who would otherwise be eligible to possess the vote or to stand for office. Examples in this category include a situation where he or she has been found guilty of a criminal offence or has been made bankrupt. This and the first type of condition are alike in that they reflect views about a person's fitness, in the broadest sense, to exercise the vote or to hold office, but the second group differs in being concerned with what may be viewed as character defects of such a type and degree as to be believed (whether plausibly or not) to justify disqualification.

The third and fourth types of prohibition, being confined to the holding of office, are central to this article. The principal aim of both types is to prevent the concentration of power in any individual or group of individuals. In this respect, however, they differ markedly from each other.

The hallmark of the third type of prohibition is that it is sequential in nature. The best example consists of limitations on the number of terms of office to which a person may be elected. The prime instance is the rule that limits the President of the

\footnotetext{
1 This has caused difficulties for as long as members of Sinn Fein have had contact with the constitutional affairs of the UK. For an early attempt to resolve the difficulties see the oath contained in the Articles of Agreement for a Treaty between Great Britain and Ireland (6 December 1921), art 4.

2 In recent years, some of the people elected to the Legislative Council of Hong Kong have proved unwilling, on account of their favouring independence from China, to swear the oath of office laid down in the Basic Law of the Special Administrative Region of the People's Republic of China, art 104.
} 
USA to a maximum of two terms of office. Formerly a matter of constitutional convention, it acquired the force of law in the Twenty-Second Amendment to the Constitution. The third type, indeed, could be viewed as a precautionary version of the second. The election to office of a given candidate is not deemed objectionable in itself. Rather, the aim is to eliminate any temptation that he might feel towards displaying high handedness in office as a consequence of repeated electoral successes.

The fourth type, by contrast, focuses on the concurrent occupation of posts. In this way, an elected representative is forbidden to hold a range of other positions during his period of office. The prohibitions can be divided into two general categories. Some are based on the doctrine of the separation of powers. As is well known, this holds that there are three kinds of governmental function - legislative, executive, and judicial - and that a person should not occupy a position of one kind while holding, at the same time, a position in either of the other two. Similar to it, but quite different in emphasis, are constitutional provisions which list a range of bodies the membership of which is deemed incompatible with the proper discharge of the office of legislator. Those that are set out in the UK's House of Commons Disqualification Act (hereinafter 'HCDA') 1975 - a statute that was prefigured in a measure of the same name in 1957 - can be taken as reasonably typical of such bodies. Its detailed provisions will be considered at the relevant points in this article.

Many constitutions have been marked by conditions for exercising the vote or standing for office that would be impossible to justify today, having been based either on the privileges deriving from the holding of property or on prejudice on the grounds of gender or religion. Indeed, historically one of the characteristics of disqualification from office has taken the form of requiring the swearing of an oath of office the terms of which were unacceptable to adherents of minority faiths. Such a device, at any rate, avoided the difficulties of formulating a legally precise definition of members of the group in question. Other disqualifications were prompted by considerations which were very important at the time but which have no bearing on the modern world (the elimination from the House of Commons of 'placemen' whose allegiance was to the Crown being a case in point). The UK, having a flexible constitution, has been able to divest itself more easily than most countries of such historical relics. ${ }^{3}$ Yet several still survive even there, and one of the purposes of this article is to inquire whether, even if they are of relatively

3 See John Waugh, 'Disqualification of Members of Parliament in Victoria' (2005) 31 Monash University Law Review 288 for an account of the disqualifications that are typical of those applicable to the parliaments of Australia. 
modern origin, these are any more defensible by the light of principle than those of former times.

\section{Principal Themes}

There is already a body of literature as to the proper scope of the franchise. ${ }^{4}$ It has not been matched by a comparable investigation concerning the limits properly applicable to the holding of office. Certainly, there has been an attempt to construct a link between the two issues by categorising the latter as the 'right to be elected' and by describing limitations on it as 'another form of disenfranchisement'. ${ }^{5}$ This is an inappropriate way of describing restraints on who may be elected to office. To be barred, for example, from voting for a person for a particular position (because, say, he has already served the maximum permitted number of terms) is very different from the archetypal instance of disenfranchisement: being denied the right to vote at all - for any candidate.

It may be asked whether some guidance is to be gained on the question of proper disqualifications on holding office from the equivalent disqualifications that are imposed on voters. Should the former reflect those that are applicable to the franchise, or is there a case for making them more - or less - restrictive? Some of those that are applicable to the former could not be replicated in terms of the latter, an obvious example being limitations on the number of terms of office that an elected official may hold. A further point of difference is that the typical electorate, in contrast to the executive or legislative component in government, will be large enough to be able to accommodate a small potentially wayward element - a consideration that may be viewed as irrelevant if a particular disqualification is characterised as possessing a punitive purpose. The issue of how many persons are typically affected by it would not then arise. Alternatively, the matter might be viewed, not in punitive terms, but exclusively as an issue of the degree of competence possessed by particular individuals - a perspective that invites the response that 'most citizens who are competent enough to elect are not competent enough to be elected'. 6

Furthermore, should disqualifications be treated as matters of overriding importance, to be imposed by the law, or should there be scope for some of them to

\footnotetext{
4 See especially Ludvig Beckman, The Frontiers of Democracy: The Right to Vote and its Limits (Palgrave Macmillan 2009) and Claudio Lopez-Guerra, Democracy and Disenfranchisement: The Morality of Electoral Exclusions (OUP 2014).

5 ibid 151.

6 Montesquieu, The Spirit of the Laws (Pt 1, Book 2, ch 2) 12.
} 
be reserved for the play of constitutional convention? Even more, should the possession of some attributes be left entirely outside the scope of constitutional rules (whether legal or conventional) to be matters for the judgement of the electorate, as going to the political unattractiveness of the candidate for office? ${ }^{7}$ There is here a fundamental difference between the conditions governing the franchise and those for attaining elected office. In view of the numbers comprising the typical electorate, the entitlement to vote could not be regulated other than on the basis of precise legal rules. The conditions for exercising the franchise are, in this sense, of foundational importance.

It is not the same with the disqualification of candidates for office. These can be disqualified either at the point when they seek to offer themselves for election or, once having been elected, by the occurrence of a mid-term event. The former is the more straightforward. To deny voters the opportunity to elect a bankrupt (for example) or a person who has a criminal conviction is to withhold from them the making of a judgement that, all things considered, persons with such failings in their records might possess potentially redeeming qualities. If this premise is accepted, various consequences follow. The opportunity should be available for the electorate to be made aware of the existence of the blemish in the candidate's past. There should also be scope for registering a vote for the individual in question; his candidature should not be excluded outright. In regard to a mid-term event, however, the only possible scope for making the judgement of the voters decisive is to require the suspect legislator to submit to a by-election.

The treatment in this article is selective. Such clearly defensible grounds of disqualification as immaturity of years will not be covered. The focus will be, within constitutional systems that are derived from British antecedents, on grounds of disqualification that do not appear to be justifiable on principle. In general terms, it will argue that these should be drawn as narrowly as possible, to be imposed only for the most compelling reasons. In this regard, it follows the view expressed in John Stuart Mill's essay of 1861, Representative Government : 'There ought to be no pariahs in a full-grown and civilised nation; no persons disqualified, except through their own default'. ${ }^{8}$ Mill was addressing here the question of the extent of the right to vote (itself a matter of considerable contention in England at the time), but the same point applies to the right to stand for office.

7 This is to assume that the electorate has a decisive role. In the case of legislative chambers with a nominated or hereditary component, for example the British House of Lords, the nominating body could be charged with the duty of complying with the standard disqualificatory conditions, and the same conditions could be held to nullify any right that is based on succession.

8 JS Mill, Utilitarianism, On Liberty, Considerations on Representative Government (HB Acton ed, JM Dent \& Sons 1972) 279. 
Indeed, it applies with greater force, since to provide otherwise would be to limit the range of choices available to the electorate.

It is necessary, while bearing that difference in mind, to note the limitations that were suggested by Mill. The only possible justification for withholding the franchise from a person, he believed, was for 'the prevention of greater evils'. ${ }^{9}$ However, it is far easier to secure assent to this general formula than it is to gain agreement on its application to particular instances. It is difficult, moreover, to reconcile this premise, particularly with its criterion of personal fault, with the four examples that Mill gives of legitimate grounds for exclusion from the franchise. These are: illiteracy (a far more common condition in the nineteenth century, though unlikely to be found amongst those aspiring to public office); not qualifying for the payment of direct taxation; being in receipt of parish relief (an early form of social security payment); and being an 'uncertified bankrupt'. ${ }^{10}$ As far as modern law is concerned, bankruptcy alone, it will be seen, has figured as a common ground of disqualification. The remarkable feature about them is that all, apart from the first, are financial in nature. Of these, only the non-payment of taxes and the receipt of parish relief, as impinging on the public finances, might be thought to form a legitimate basis for disqualification.

The view that limitations on the franchise should be confined to as narrow a range as possible accords with the characterisation of the right to vote as a fundamental human right. Increasingly during the last 70 years all manner of political claims have been advanced in the language of individual human rights: the present subject has not escaped this trend, as a survey of the principal texts shows. Article 21 of the Universal Declaration of Human Rights simply enunciates the general norm: that 'everyone has the right to take part in the government of his country, directly or through freely chosen representatives'. Article 25 (b) of the International Covenant on Civil and Political Rights goes further, conceding the legitimacy of some limitations on the right provided that they do not amount to 'unreasonable restrictions' on it. More relevant to the themes of this article, it declares a 'right to be elected' - an inappropriate characterisation since it implies a corresponding duty to elect on the part of others. It is more accurately defined as a right to stand for office. Finally, and most remarkably, the drafting of the European Convention on Human Rights is cautious about placing the idea of individual rights at the core of the guarantee. The First Protocol, Article 3, is couched in terms of a

9 ibid.

10 ibid 280-82. 
collective right, in guaranteeing 'free elections' such as to ensure 'the free expression of the opinion of the people'. ${ }^{11}$

\section{Separation of Powers Considerations}

If the focus of attention is moved away from the right to vote towards eligibility to hold public office, considerations that are based on the separation of powers start to enter the picture. A perusal of the HCDA 1975 reveals at least one provision which is clearly based on that doctrine. Section 1 (1) (a) lists a wide range of judicial positions which may not be held at the same time as membership of the House of Commons. On principle any such prohibitions that are based on the separation of powers should also extend to the House of Lords since they are both legislative chambers. Instead they are confined to the Commons - a limitation that is expressed in the very title of the HCDA 1975. Clearly, theory has given way here to pragmatic considerations. The Commons having long been the more powerful of the two houses, the disqualifications that are applicable to it will have been of far greater significance than those relating to the Lords. Furthermore, the extension of the terms of the HCDA to the House of Lords would have caused special difficulties in regard to the judiciary in view of the fact that, prior to the Constitutional Reform Act 2005, that House was also the seat of the highest court in the land.

The doctrine of the separation of powers is too well known to justify an extensive treatment here. Our account will be confined to those neglected aspects of the subject that are relevant to the theme of disqualification. The overriding point that needs to be emphasised is that it is the concurrent occupation of posts in more than one branch that the doctrine rejects. The sequential occupation of such posts would seem acceptable from its perspective. Indeed, it does not appear to be an objection to the sequential occupation of such posts by a single individual that the posts are at the pinnacle of the respective areas of government. This point is illustrated by the career of William Howard Taft who, having served as President of the USA 1909-13, became a Justice of the Supreme Court and eventually Chief Justice (1921-30). ${ }^{12}$

11 Litigation on the right to vote is more plentiful than on the right to stand for office. Cases on the former include the classic authority in English law: Ashby $v$ White [1703] 2 Ld Raym 938, 92 ER 126, and the recent case on the right to vote in elections to the European Parliament: Case 650/13 Delvigne v Commune de Lesparre-Medoc [2016] 1 WLR 1223.

12 Remarkably, too, he had been a federal judge before embarking on the political phase in his life. 
That the separation of powers does not extend to the sequential occupation of posts in the several branches of government could result in a situation where the same personnel may be involved (in turn) in the creation, the enforcement, and the interpretation of the same law. The individuals concerned may have been, at the outset, members of the legislative body at the time when it enacted the law. They might have gone on to serve in the executive branch, charged with its enforcement. Finally, one or more may have ended up sitting on a judicial tribunal which interprets and enforces it. So far as the UK is concerned, such a state of affairs would be unlikely, if only on account of the constitutional convention that members of the senior judiciary stay in post until retirement. At any rate, if they leave the bench they could not take up any position that would be even remotely political. Employment in the City or in academic law would seem acceptable (as reflected in the career of Mr Justice Fisher, who left the High Court for banking in the late 1960s, and that of Lord Justice Jacob, who quit the Court of Appeal for a professorship in 2011). Consequently, if there is to be any such combination of career paths it can occur only if the political phase precedes the judicial phase - itself unlikely in recent times since recruitment to the higher judiciary (at least) has been avoided from persons who have had significant political careers. ${ }^{13}$

There has been a certain tolerance of overlap, at the margins, as between occupancy of offices in the three areas of government. Under the HCDA 1975 justices of the peace are not disqualified from membership of the House of Commons despite the fact that their core role, even if at the lowest court level, is judicial in nature. This accommodation is rendered all the easier since the judicial arm of government contains at least one inbuilt safeguard against the sort of concentration of power that the doctrine of the separation of powers seeks to prevent. This takes the form of the rules concerning disqualification for potential bias. Although a person may be an MP at the same time as sitting as a magistrate, he will be subject to challenge in the latter regard if he is allocated a case which might reasonably be viewed as calling into question his judicial impartiality.

There is, however, a far more substantial departure from the separation of powers doctrine that inheres in those constitutional systems that are characterised by the existence of a parliamentary executive. These are systems that embody a rule (whether legal or conventional) that requires all members of the government to hold a seat in the legislature (or, at least, to have the prospect of the early attainment of a seat). Such an arrangement, far from being considered conducive

13 It was not always so. There long existed a convention that, if the position of Lord Chief Justice fell vacant, the Attorney-General of the day had the right of first refusal of the post. In this way an individual could experience a rapid transition from a leading political post to the leading judicial office. 
to tyrannical government, is viewed in the countries which observe it - preeminently the UK - as positively advantageous. Walter Bagehot was certainly of this opinion, describing the Cabinet in a profusion of metaphor as 'a combining committee - a hyphen which joins, a buckle which fastens the legislative part to the executive part of the state'. ${ }^{14}$ But that is to understate the extent of the paradox. It would have been more accurate to describe the whole of the ministerial ranks as forming that buckle since the essential point is that it is they who are bound by the doctrine of collective responsibility. Moreover, to press Bagehot's figure of speech a little further, it could be that the buckle is drawn too tight for constitutional comfort. That is, the degree of overlap in membership may lead Parliament - to be more precise, the House of Commons - to act as little more than a rubber stamp for the will of the executive.

An approximate co-existence with the separation of powers doctrine is secured in section 2 (1) of the HCDA 1975, which limits to 95 the number of holders of ministerial office who may sit and vote in the House of Commons. The figure of 95 appears to be rather arbitrary, amounting to nearly $15 \%$ of the total complement of 650 MPs. It is the latest in a line of such provisions. ${ }^{15}$ The limitation in section 2(1) is not to be confused, as it often is, with the constraints imposed by the Ministerial and other Salaries Act 1975. The theme of the latter, as its name suggests, is salaries, both their amount and the persons to whom they are payable. In particular, it places a cap on the total number of persons who - irrespective of whether they sit in the Commons or the Lords - may be in receipt of a ministerial salary. ${ }^{16}$ Since ministers are remunerated as a matter of course for their services in that capacity, it appears to cover largely the same ground as section 2 (1). Both limitations, alike, act to place a curb on the extent of Prime Ministerial patronage. Inevitably there will be a substantial overlap as between the operation of the two provisions, which perhaps accounts for the fact that they are not considered side

14 Walter Bagehot, The English Constitution (1867, RHS Crossman ed, Fontana 1963) 68.

15 Stephen's Commentaries on the Laws of England (FH Lawson ed, 20th edn 1938) vol I, 358, argues that the rationale of the limitations is to secure an adequate representation of the government in the House of Lords. If so, it is a strangely oblique way of doing so. It would have been more straightforward to stipulate a minimum number to occupy seats in the House of Lords.

16 The Ministerial and other Salaries Act 1975 is the more detailed and complex measure. The core provisions are sch I, pts II-IV. Sometimes payment for a particular office is indicated by title (eg, Chancellor of the Exchequer, Attorney-General). More often classes of office are designated, each subject to numerical limits (eg, Secretary of State with a maximum of 21, and Minister of State subject to a maximum of 50). The existence of numerical limitations raises the problem of identifying the persons who are to be disqualified in the event that the numbers exceed the limits. The HCDA 1975, s 2 (2), addresses the issue but only in the context of the cap of 95 on the number of ministers who may sit in the Commons. 
by side in the literature. ${ }^{17}$ Yet there exist significant differences between them, and there must be compliance with each in turn. The HCDA provision extends only to the House of Commons, a limitation which (as already noted) may be rationalised on the ground that it is the more powerful of the two legislative chambers. The Ministerial and other Salaries Act, by contrast, encompasses both houses. It might be viewed on that account as a purer expression of the separation of powers, except for the fact that another of the features of that Act - the payment of ministerial salaries - is a consideration that has no part to play in that doctrine in its classic form. It does, however, have the characteristic that it is all the easier to secure compliance with it, if (as has happened from time to time) the number of ministers in excess of the permitted maximum can be persuaded to forego their salaries in that capacity.

\section{Direct Disqualification: Guarding Against the Undermining of Constitutional Government}

It is now necessary to move the discussion beyond the separation of powers and into the sphere of disqualifications that cannot be derived, or (at most) may only marginally be derived, from that doctrine. For this purpose, the subject-matter will be divided into two broad categories. The one, examined in the present section, comprises standard instances of disqualification as imposed by constitutional norms ('direct disqualification'). The other, to be discussed in Section 6, examines instances of disqualifications that are derived from the rules of non-state organisations ('reverse disqualification').

The most important direct disqualifications are those that keep at some distance from political influence the persons who, by virtue of their position, are so placed as to undermine constitutional government. In general, they require that certain groups that have responsibility for aspects of governance remain neutral in their dealings with those who compete for political power. Civil servants and judges are pre-eminent examples of those who must hold themselves above the political fray. The same applies even more to the armed forces and the police, to which particular attention will be given here, since they are in a position to use physical force in the cause of subversion. In fact, the police, the armed forces and the civil service could all be viewed as parts of the executive branch of government,

17 There is sometimes confusion even when the two statutes are considered together. An example is Chris Bryant, Parliament: The Biography - Reform (Penguin 2014) vol 2193 : ‘[...] two Acts of 1975 limited the number of ministers in either house to 109 and the number of MPs in paid jobs to $95[\ldots]$ '. 
and to the extent that they are so regarded this is to be treated as a continuation of the discussion in the previous section of the separation of powers.

\subsection{The Armed Forces}

In some constitutions, at certain times, it has gone without question that there is a conjoining of the highest political and military posts. For much of British history, for example, the King in person led his forces into battle. ${ }^{18}$ Yet history is replete with examples of where the military has intervened improperly in the conduct of political affairs. It is not surprising that, with the beginnings of constitutional government, measures were taken to prevent the military from suborning civilian rule. Ancient Rome, in particular, was alert to this danger. When in 49 BC Julius Caesar led his army across the Rubicon, the river that marked the boundary of the Roman Republic, this was taken as a clear challenge to the civil authority of the Senate. If the main threat from the armed forces lies outside the formal structures of office holding, in the shape of extra-constitutional force, the drafting of constitutions can do little to avert danger from this quarter. Nevertheless, one of the headings of disqualification listed in the HCDA 1975 - section 1 (1) (c) - applies to 'a member of any of the regular armed forces of the Crown'. ${ }^{19}$ The requirement that the person be in the regular armed forces would mean that members of a citizens' militia or a reserve force, understandably, would not be caught by the prohibition. ${ }^{20}$

Even though written constitutional guarantees would be of little service in staving off the threat of military rule it is still possible to find for them a more limited, but valuable, function.

In English constitutional history concerns about the intrusion of the military in civil matters have predominantly taken the shape of measures aimed at avoiding a 'standing army'. It is to be noted that the relevant legal provision, Article 6 of the Bill of Rights 1689, forbids a standing army within the Kingdom in peace time 'unless it be with assent of Parliament'. Any prohibition of the existence of MPs who were also soldiers would thereby reduce the likelihood of a voting bloc in a position to achieve that assent. Equally, the presence in the legislature of members of the armed services could be viewed as highly undesirable since it could bring improper pressure to bear on non-service members. Two examples, each drawn from critical historical junctures, may be cited. One occurred during the First World

18 The last to do so was George II in 1743 during the War of the Austrian Succession.

19 See, similarly, art 54 (1) (b) of the Constitution of Malta.

20 See further HCDA 1975, s 3. 
War, when the Military Service Bill was introduced in the House of Commons on 5 January 1916 with the aim of introducing conscription. The proceedings were attended by no fewer than 165 MPs (out of a total of 630) who were serving in the forces, all conspicuous by the wearing of military uniform. ${ }^{21}$ The other was in May 1940, during the crucial debate on the fall of Norway which led to the defeat of the government of Neville Chamberlain, when the condemnation of its war record was led by Sir Roger Keyes in the regalia of the highest naval rank, Admiral of the Fleet.

Army officers were authorised to sit and vote in the House of Commons only at the outset of the First World War, by the House of Commons (Commissions in His Majesty's Forces) Act 1914 - a provision that was cautiously stated not to be applicable to future Parliaments. ${ }^{22}$ The strikingly unusual situation that was now created, whereby a person could move relatively freely between military and political roles, was illustrated by the career of Winston Churchill. At the outbreak of the war, Churchill was already a leading political figure, as both an MP and a member of the Cabinet (First Lord of the Admiralty, the political head of the Royal Navy). In November 1915, he resigned his post in the Cabinet, while remaining an MP, to join the regular army at the front where he was posted until May 1916. The dual nature of his position during this period, poised between politics and the army, was brought out in several ways, most notably in his delivering a controversial speech on war policy in the House of Commons on 7 March 1916 during a period of leave. Nothing could have illuminated more clearly than this the absence of a cordon sanitaire between servicemen and those responsible for their political direction.

\subsection{The Police}

The relevant heading here is section 1 (1) (d) of the HCDA 1975: "a member of any police force maintained by a police authority”. It, too, relates to a disciplined force, but with a somewhat different purpose. The danger that it seeks to guard against can be expressed most generally in terms of the emergence of a 'police state'. ${ }^{23}$ But in so far as this phrase identifies with sufficient precision a political situation that is to be avoided at all costs, the possibility of its realisation can be avoided in ways apart from prohibiting police officers from occupying seats in the legislature. These would include any of a number of safeguards: powers of arrest and search that are

21 See John Rae, Conscience and Politics: The British Government and the Conscientious Objection to Military Service 1916-1919 (OUP 1970) 33.

22 House of Commons (Commissions in His Majesty's Forces) Act 1914, s 2 (2).

23 See Brian Chapman, Police State (Macmillan 1971) for a comparative historical analysis of the concept. 
closely confined; the retention of local police forces in preference to a national force; ${ }^{24}$ and maintaining the principle of constabulary independence. ${ }^{25}$

The most striking fact about the position of the police in relation to Parliament is that, in a series of statutes enacted in the nineteenth century, they were categorically denied the vote. This remained so until the Police Disabilities Removal Act 1887 comprehensively repealed the seven statutes in question. Yet the disqualification would have possessed an effect that was more symbolic than practical. To deny the vote to persons who would not have qualified for it on the basis of the possession of property would scarcely have made much difference to their position. Its impact would have been felt on an increasing scale only with the expansion of the general franchise from the late nineteenth century onwards. In any event, the position of the police does exhibit some degree of congruence between limitations on the right to vote and limitations on eligibility to serve in Parliament. $^{26}$

At this point, some observations are in order about the armed forces and the police together. The capacity of these groups to endanger constitutional government does not depend to any significant extent on whether their members occupy seats in the legislature. It would be difficult to believe that a minimal tolerance of overlap between their numbers and membership of the legislature would drive constitutional arrangements down a slippery slope towards oppressive government. If there were such a danger, it would be more likely to be posed by those who are in positions of command than by the rank and file membership of the forces. ${ }^{27}$ However, as with other instances of legal regulation, it was far simpler to impose a complete ban on overlap with membership of the House of Commons than to enter into speculation as to how much of an overlap would set in train any movement down that path. Quite generally, then, the rule that members of the police or the armed forces may not concurrently be Members of Parliament is best viewed as a

24 This was roundly rejected as providing a criterion for the existence of a 'police state' by a Royal Commission. See Home Office, Report of the Royal Commission on the Police (Cmnd 1728, 1961-62) para 135.

25 Most topically, so far as concerns the UK, a Police and Crime Commissioner (an official who is either directly elected or appointed by an elected local mayor) has overall responsibility for the policing of a particular area and may not hold the post simultaneously with a number of other roles. It was created by the Police Reform and Social Responsibility Act 2011. See ss 64-68 for the grounds of disqualification, which incorporate, but also go beyond, those set out in the HCDA 1975. 26 The prohibition had some lingering effect in the shape of litigation as to whether members of the Royal Ulster Constabulary were entitled to vote in elections for the UK Parliament: Hunter $v$ M'Kinley [1923] 2 IR 165.

27 This was reflected in the 'Self-Denying Ordinance' of 1644 whereby Oliver Cromwell, as part of the 'New Model Army,' persuaded members of both Houses of Parliament to resign their commissions. 
manifestation of an important wider principle: that they must observe strict political neutrality.

\section{Reverse Disqualification: Safeguarding Organisational Independence}

Hitherto we have considered instances of disqualification in the standard sense, imposed by a legal source such as statute or the constitution. Similar to these in effect, but quite different in emphasis, is the device of 'reverse disqualification'. This designates the situation where members of an organisation are forbidden to occupy political posts, not by reason of a law such as the HCDA 1975, but because the prohibition is imposed by the organisation itself. To be more precise, it is the rules of the organisation, rather than the fact of membership of it, that form the bar to the overlap. This is in contrast to the headings of disqualification covered in Section 5, where the mere fact of being a member of a police force or the civil service (for instance) is the decisive consideration. The main point behind reverse disqualification is the concern of some organisations to preserve their independence from political involvement - an objective that is achieved by forbidding members or (at least) the more prominent categories of member from seeking, attaining or retaining political office. The rules of a wide variety of bodies may be identified as falling under this heading.

Some churches, for example, are apprehensive that the holding of political positions by ministers of religion, far from injecting a spiritual element into the governance of the country, will lead to the secularisation of the faithful. The Roman Catholic Church is a case in point, its Code of Canon Law stipulating:

'Clerics are forbidden to assume public offices which entail a participation in the exercise of civil power'. ${ }^{28}$

The Church thereby distances itself from politics in two ways: in the rule that clerics may not hold political positions; and, of equal significance, in the fact that expression to the rule is given through ecclesiastical, rather than secular, law. ${ }^{29}$

28 The Code of Canon Law (1983), Canon 285, para 3.

29 Ministers of religion, like others with demanding occupations, would normally find it impracticable to combine their duties with the burdens of seeking office and serving in the legislature. However, the non-elective and part-time nature of membership of the House of Lords renders it a suitable forum for testing the issue of principle divorced from practical considerations. In this respect it is noteworthy that in recent years two holders of the office of Chief Rabbi have accepted appointment as life peers. 
The position of ministers of religion, historically, has provided an example of the interplay of reverse disqualification with the standard case of direct disqualification. The existence of the latter should not be surprising in view of the religious discrimination that has disfigured much of British history. Suffice it to say that its impact, gradually diminished over the years, has been terminated by the House of Commons (Removal of Clergy Disqualification) Act 2001. This short statute provides simply that a person is not barred from being an MP merely because he has been ordained or is a minister of any religious denomination.

The provisions relating to the broadcasting media also embody elements of both types of disqualification. In general the power of the media is such that they are in a position to subvert the integrity of the democratic process, and in more subtle ways than the methods that are available to the army or the police. But, as with those forces, their power to do so is not to be gauged by whether their representatives are permitted to hold seats in the legislature.

The problems of maintaining the integrity of the democratic process are especially acute in regard to the broadcasting media. The fact that some parts of the broadcasting media are under public control, and others are in private hands, is reflected in the dual approach of the British legislation. The prohibition on any of the Governors of the British Broadcasting Corporation (BBC) serving as an MP follows the usual pattern of the HCDA Act $1975 .^{30}$ The equivalent provision for commercial broadcasting has an element of reverse disqualification. The disqualification applies to members of its regulatory body, the Independent Television Authority (ITA) subsequently renamed the Independent Broadcasting Authority (IBA). Thus far it follows the standard instances of direct disqualification in being embodied in legislation. However, its emphasis differs from those instances, in stipulating that a person may not be a member of the body as long as he is a member of the House of Commons. $^{31}$ This may appear to be no more than an issue of presentation. However, in taking the linguistic form of reverse disqualification, it is plain that the central purpose of the prohibition is to safeguard journalistic impartiality rather than to protect the legislature from the presence of alien influences. Since the IBA is simply an umbrella organisation, the function of which is to enter into arrangements with companies for the purpose of broadcasting commercial programmes, it has been necessary to supplement

30 HCDA 1957, sch 1, pt 3.

31 Television Act 1954, s 1 (6). 
its regulatory framework with rules of equivalent effect that are applicable to the individual broadcasting companies. ${ }^{32}$

Finally, amongst the various organisations the rules of which can impinge on membership of the legislature, special mention should be made of political parties. These are relevant to the present topic, not as sources of employment which can conflict with the proper performance of the duties of a legislator, but because sponsorship by a political party is, for the most part, a precondition of a reasonable prospect of being elected to office. This, in turn, renders the party rules of comparable importance to those that are imposed by the HCDA 1975. Unlike the latter, however, there can be variations in the rules across the various parties, or even as between different local organisations within the same party. A point of principle on which such organisations have needed to take a stance, for example, is on the question of whether a party member, once elected to the Commons (or, for that matter, appointed to the House of Lords) is required to surrender other positions (on a local council, for example). The layers of government in the UK have increased so much over the last 20 years that this aspect to the subject can only gain in importance. To the duality of representation at Westminster and in local authorities have been added regional assemblies (the Scottish Parliament, the Welsh Assembly, and the Northern Ireland Assembly) and (while the UK remained a member of the European Union) the European Parliament. ${ }^{33}$

\section{Punitive Disqualification}

It is now necessary to examine grounds of disqualification that are not driven by the need to preserve constitutional safeguards in the narrow sense of that term. They may be viewed, rather, as giving expression to a desire to 'punish' those who are deemed to have failed in their civic obligations. Alternatively, the character of the persons concerned as revealed in their conduct might be such that they are

32 This is exemplified by the 'broadcasting rules' which required Matthew Parris, formerly an MP but now a leading political commentator, to resign his seat in Parliament in 1986, on accepting appointment as presenter of a political programme on London Weekend Television, an Independent Television franchise holder: see Matthew Parris, Chance Witness: An Outsider's Life in Politics (Penguin 2003) 340.

33 Not surprisingly, it is the smaller parties that have been more indulgent on this issue. Examples can be given of Liberal Democrats who have been allowed to sit simultaneously on local authorities and in the House of Commons (eg, John Leech MP for Manchester Withington 2005-15 while initially retaining his seat on Manchester City Council), or on local authorities and in the House of Lords (eg, Baroness Pinnock, a life peer from 2014 while serving on Kirklees Metropolitan Borough Council from 1987). 
thought unworthy of being allowed to participate in the political process, at any rate until such time as they have expiated their guilt. Such failings may have been made manifest in the most direct way, by their having broken the criminal law, or they may have fallen below some other fundamental standards of conduct in civic life.

\subsection{Criminal Conviction}

A criminal conviction, like several other factors considered in this article, may serve either or both of two purposes: it may act to disenfranchise a voter, or it may be a ground for disqualifying a person from holding office. So far as the latter aspect is concerned, this is one of the easiest grounds of disqualification to defend, the only scope for disagreement being its extent and duration. The same claim cannot be made of the former, which has attracted some attention in recent years in both the UK and the USA though for rather different reasons.

In Britain, there was considerable opposition to the ruling of the European Court of Human Rights in Hirst $v$ UK (No 2) ${ }^{34}$ that the UK, in denying the vote to all prisoners, was in breach of the right to free elections contained in Article 3 of the First Protocol to the Convention. Objections were voiced as a matter of principle - most prominently by the Prime Minister, David Cameron - to the very idea that an imprisoned person should be allowed to exercise the franchise. There was no suggestion, however, that the disqualification had had any impact on any election result. This was in contrast to the position in the USA, where (apart from the issue of principle) it is believed that the felony disqualification rule may have tipped the scales in favour of George W Bush in the presidential election of $2000 .^{35}$

In regard to MPs, the main provision is the Representation of the People Act 1981. ${ }^{36}$ This short statute provides that a person is ineligible to stand for, or sit in, Parliament while detained if he has been convicted of a criminal offence and he has been given a prison sentence of one year or more. ${ }^{37}$ The measure was prompted by

34 Hirst $v$ UK (No 2) (2006) 42 EHRR 41.

35 The reason was that those affected by the rule tend to come from the poorer sections of society, who traditionally support the Democratic Party. This may have enabled the Republicans to win the key state of Florida.

36 The overriding emphasis of Jeremy Horder, Criminal Misconduct in Office: Law and Politics (OUP 2018) is on the offence of misconduct in public office, particularly in the context of the MPs' expenses scandal of 2009. As such, most of it is relevant to section 8, below.

37 It is another instance, if little noted, of what have been termed the 'collateral consequences of conviction': see Zachary Hoskins, 'Criminalization and the Collateral Consequences of Conviction' (2018) 12 Criminal Law and Philosophy 625. 
a case at the height of the troubles in Northern Ireland. Bobby Sands, a member of the IRA who in 1977 had been sentenced to 14 years' imprisonment for possession of firearms, chose in 1981 to stand as a candidate at a by-election. Although Sands was returned for the seat, the case did not go on to expose the problems of accommodating an incarcerated legislator since he went on hunger strike and died shortly afterwards.

Breaches of the criminal law that are committed by legislators (whether serving or aspirant) differ from criminality in the general population in that they will often be politically motivated. It might be thought that acts of civil disobedience committed by them, in contrast to the standard forms of criminal behaviour, should be shielded from the wider consequences of incurring a conviction. ${ }^{38}$ In accordance with the general tenor of the law, however, there is nothing in the legislation that makes special provision for the motives of the criminal legislator.

The question of whether a person should be disqualified from serving in the legislature by reason of having committed a crime of a certain level of seriousness has several facets. Like the denial of the vote to the individual citizen for the same reason, it may be nothing more than a judgement on the moral unworthiness of the person concerned. In the case of a legislator, there are, additionally, considerations that are unique to the heading of felony disqualification: the practical problems of fulfilling the several tasks of the role while being subject to physical confinement. On the one side are to be weighed the obstacles confronting the incarcerated legislator: attendance in the legislative chamber; taking part in its votes (is proxy voting allowed?); meeting with constituents (and voters generally at election time). ${ }^{39}$ On the other side are to be considered the incidental (but nevertheless substantial) restraints that would apply as a matter of course to prisoners in general (in regard to such matters as freedom of correspondence). ${ }^{40}$ These weigh most heavily on any legislator who is imprisoned for a period which, though substantial, is less than the term of one year that results in the compulsory vacating of his seat. ${ }^{41}$

38 Such a case was that of Terry Fields, a Labour MP who gained a conviction in July 1991 for refusing to pay the 'poll tax', the controversial local tax introduced by the government of Margaret Thatcher in 1988. Being imprisoned for 60 days, he was not disqualified under the 1981 Act.

39 Some of these points relate only to legislators who are elected and would have little, if any, application to those who are not (for example, members of the House of Lords).

40 See Graham Zellick, 'The Imprisonment of Members of Parliament' [1977] Public Law 29, 33-47, for discussion of such matters as freedom of correspondence and attendance in the Commons for such basic purposes as to be sworn in as an MP.

41 Logically, however, if an MP is still capable of discharging his duties while subject to a prison sentence of one year, he should be able of doing so indefinitely. From this point of view the recall condition of any custodial sentence in the Recall of MPs Act 2015 - see n 43 - is more sensible. 
Apart from the general terms of the 1981 Act, there is a special set of provisions relating to persons whose crime consists of having committed corrupt or illegal practices at an election. ${ }^{42}$ A conviction for any of these offences results in the immediate vacating of the MP's seat. Furthermore, amongst other penalties, he may be disqualified from standing as an election candidate for a period of 5 years (in the case of a corrupt practice) or 3 years (in the case of an illegal practice). This last element calls for some comment. It has already been noted that one approach to the question of disqualification would be to leave the issue of whether a person should be entrusted with the holding of office to the judgement of the voters. The making of a disqualification order pre-empts the making of such a judgement in a way which goes against one of the declared themes of the present article. However, to allow the decisive voice to the voters would be to ignore the special nature of the crime that has been committed here. The very fact of a person having been found guilty of an electoral offence would mean that, in the event of the likely repetition of his misconduct, it would be unwise to repose trust in the outcome of any electoral process in which he participates as a candidate. ${ }^{43}$

Some general points, finally, should be made about the range of techniques of a broadly punitive nature that are available for use in the realm of disqualification. An automatic disqualification may be laid down by the law consequent on infliction by the court of punishment of a certain level of severity, as under the Representation of the People Act 1981. Or the decision to disqualify could be left to the discretion of the trial judge, who may be empowered to lay down a period of disqualification as an integral part of the punishment imposed by the court. Alternatively, the issue could be left outside the criminal procedure system by being entrusted to the decision of a licensing authority that has jurisdiction in the relevant area of social life. ${ }^{44}$ Finally, there could be a judicial procedure that, like the licensing process, does not serve as an adjunct of the criminal trial but in this instance is specifically and exclusively aimed at the question of the possible

42 Representation of the People Act 1983, s 173.

43 It should be noted that, in the case of legislators, there exist various ways in which, apart from disqualification in the strict sense, criminal activity may result in loss of office. The person concerned may be expelled from the legislature by his fellow legislators or be subjected to impeachment proceedings (a device that is traditionally deployed against executive officials rather than members of the legislature: but see Raoul Berger, Impeachment: The Constitutional Problems [Harvard University Press 1974], ch 7). Alternatively, removal may be at the instigation of the voters in the form of recall. Under the UK's Recall of MPs Act 2015, for example, one of the events that can activate the procedure is that a person, after becoming an MP, has been convicted of a criminal offence in the UK resulting in a custodial sentence.

44 See generally Andrew von Hirsch and Martin Wasik, 'Civil Disqualifications Attending Conviction: A Suggested Conceptual Framework’ (1997) 56 Cambridge Law Journal 599. 
disqualification of an individual. The last possibility is a technique that is to be found in the commercial sphere. A person may be made subject to judicial proceedings which, if he is judged 'unfit' to be concerned in the management of a company, may culminate in an order forbidding him from holding a directorship in a company for a certain period of time. ${ }^{45}$

\subsection{Failings in Other Civic Obligations}

Various personal failings, whether actual or supposed, have been used as the basis for the denial of rights in the elective process. The most noteworthy is bankruptcy, a commonly encountered disqualification in those legal systems that have been influenced by English law. It will serve as our principal example.

Bankruptcy, as a ground of legislative disqualification, dates back to the nineteenth century at least. Yet it was omitted from the HCDA 1975 when that statute placed the subject on a consolidated basis. This reflects two distinctive aspects of this head of disqualification: that it applies to membership of the House of Lords as much as to the House of Commons; and that its rationale is quite different to the grounds contained in the HCDA. Rather than being founded on potential threats to the functioning of the governmental process, it appears to embody a punitive element or, at least, a view that a bankrupt is not worthy to take part in the legislative process.

There is an important question of principle here which does not appear to have been explored. Why should inability to pay one's debts be a barrier to the holding of a seat in the legislature? There are positions where the presence of such a bar is entirely justifiable. Instances would be the offices of trustee, agent, or company director. These are characterised by two features which render the financial integrity of those who hold them of the utmost importance. They act as custodians of other people's property. Furthermore, redress against them is typically sought in the form of an order for monetary compensation - an award which will be of little avail if the defendant is bankrupt. Neither of these considerations applies to members of the legislature.

The rationale of bankruptcy as a ground of disqualification might be that it is taken as exhibiting a degree of financial recklessness that is considered unbecoming of the holder of a public position. Yet many a successful holder of political office has been improvident in money matters. Perhaps the real concern, rather, is that the impecuniosity of an MP might render him vulnerable to improper

45 The period may be between two and fifteen years. The jurisdiction was conferred by the Company Directors Disqualification Act 1986. 
pressures. Even so, it would be inappropriate to use a vague concept such as improvidence as a benchmark for disqualification from office. It is far better to deploy a clear, publicly available, marker of the sort that is provided by a bankruptcy adjudication. Alternatively, to file for bankruptcy might be taken as evincing a wish to escape one's financial responsibilities. Certainly, it is sometimes the debtor who, in taking the initiative, displays such a wish. More often this step is forced on him by his creditors. Finally, and most significantly, if there is a 'punitive' element in the bankruptcy disqualification it is difficult to see why, like the felony disqualification, it should not equally disqualify the individual voter from being able to cast a vote.

Sometimes bankruptcy and criminal conviction have resulted from the same disreputable conduct. But such a link is contingent only. More generally, the failure to pay one's creditors has sometimes been associated, in terms of degree of misconduct, with conviction for a criminal offence. The conjunction was understandable as late as the nineteenth century, when imprisonment for debt was common. Yet, in view of the tenuous link, it would be difficult today to base the disqualification on such an association.

There is at least one respect in which felony conviction and insolvency do raise similar issues. For how long should the disqualification, once applicable, continue? Should the possibility of 'rehabilitation' be permitted? In practical terms this would mean that prisoners who have served their term of imprisonment would have the vote restored to them, or be permitted once again to serve in the legislature, as would (by analogy) debtors who have repaid their creditors in full. The former will then have paid their (figurative) debt to society, as the latter will have paid the (literal) debts that they owed to their creditors. It will be recalled that Mill would have limited withholding of the vote only to the case of a bankrupt who was 'uncertified' - an expression of unclear meaning - until such time as he had paid his debts. ${ }^{46}$ Similarly, Article 47 (1) of the South African Constitution denies the right to vote for, or to serve as, a member of the National Assembly only to insolvents who are 'unrehabilitated'. Likewise, Article 102 (1) (c) of the Constitution of India disqualifies any 'undischarged insolvent' - a precise term in English law, at any rate, which refers to the period of disqualification that terminates one year after the bankruptcy. ${ }^{47}$

A focus on instances of actual bankruptcy tends to marginalise those cases where individuals have teetered on the brink of such a state of affairs. In one case, that of Jeffrey Archer in 1974, apprehension of an imminent bankruptcy led to a situation where he voluntarily stood down as an MP in preference to waiting for the

46 Mill (n 8) 282.

47 Insolvency Act 1986, s 279 (1). 
blow to fall with its concomitant danger of a by-election being held at an unfavourable time from the perspective of his party. ${ }^{48}$ Relatively little known, despite its far-reaching potential consequences, was the possible bankrupting of a significant number of Conservative MPs in the early 1990s. As 'Lloyd's Names' they were guarantors of the debts of the giant insurance market, Lloyd's of London. Their number, estimated at about 24, was large enough to place in jeopardy the existence of the Conservative government of John Major. For no sooner had Major's government been returned at the General Election of 1992 than a series of by-election losses started to reduce his majority of 21 seats. ${ }^{49}$ Indeed, several aspects of the episode might well have revealed how arbitrary could be the workings of the bankruptcy disqualification rule. First, there was the relatively large concentration of MPs who were potentially affected by the rule. This, in combination with the parliamentary nature of the executive in the UK, would have had serious consequences for the survival of the government. Secondly, and of greater significance, matters had been brought to such a pass, not by reckless risk taking on the part of the MPs in question, but by the number of unexpectedly large insurance claims brought in the USA that had a severe impact on Lloyd's. ${ }^{50}$

A declaration of bankruptcy is but one way in which a person may avoid payment of his debts. It may be avoided by the expedient of carrying on one's business through the medium of a limited company, a shield which does not expose the individual to the personal consequences of being adjudicated bankrupt. The making of an individual voluntary arrangement (IVA) is another such method, being an attempt (frequently unsuccessful) to stave off bankruptcy. English law has become increasingly sensitive to the range of orders, other than a bankruptcy adjudication, which may betoken financial shipwreck. This is exemplified in the Police Reform and Social Responsibility Act $2011,{ }^{51}$ where the disqualificatory factors, although broadly following the same pattern as those contained in the HCDA 1975, extend to the making of a range of financial orders apart from bankruptcy in the strict sense. This extension is entirely justifiable since, where a person has been made the subject of such an order, any element of

48 Archer, who went on to a successful career writing popular novels, and also to membership of the House of Lords, had been a victim of a fraudulent investment scheme.

49 The threat to the viability of his administration would have come at two points: while seats were vacant (when there would be a reduction in both the number of Conservative representatives and the total complement of MPs); and once the seats were filled, if they were captured by other parties at the ensuing by-elections.

50 See Adam Raphael, Ultimate Risk: The Inside Story of the Lloyd's Catastrophe (Bantam Press 1995).

51 See $\mathrm{n} 25$ for the background to this Act. 
wrongdoing that led to financial difficulties may well be the same as an instance of bankruptcy in the strict sense.

The modern statement of the disqualification in English law is section 266 of the Enterprise Act 2002, taking effect as a new section 426A of the Insolvency Act 1986. Its basis is the making of a 'bankruptcy restrictions order' (BRO) - an order that disqualifies a person from 'membership of the House of Commons' or from 'sitting or voting in the House of Lords'. No longer, therefore, does the mere fact of having been made bankrupt disqualify a person from sitting in Parliament. A BRO needs to be made - an order that is issued by the court on an application being filed by the Secretary of State. There are various points to be made in favour of, and against, this change in the law. The choice of the Secretary of State as the focal point of enforcement opens up the possibility of the intrusion of political factors into the process. On the other hand, the statute lists several considerations that are to be taken into account by the court which reflect the fact that there are various degrees of fault in this area, encompassing both the factors that led to the bankruptcy $^{52}$ and the post-bankruptcy conduct of the insolvent. ${ }^{53}$ The harshness of disqualification is thereby reduced even if the UK has not gone as far as removing it entirely. ${ }^{54}$

Finally, other alleged failings in civic duties should also be addressed. We have already noted Mill's view that the failure to pay taxes or being in receipt of parish relief are legitimate grounds for the denial of the vote. ${ }^{55}$ Yet each of these states of affairs may be brought about by a variety of reasons. Another alleged fault would be the refusal to perform compulsory military service. There is an historical instance of such refusal incurring a penalty. Conscientious objectors in the First World War were denied the vote for several years after the conclusion of hostilities. This disqualification was slipped into the Representation of the People Act 1918, ${ }^{56}$ a statute which is better known for its liberal content in admitting women to the franchise (though not, at that point, on the same terms as men). More remarkably,

52 Insolvency Act 1986, sch 4A, s 2 (2), lists whether, for example, the bankrupt had indulged in 'hazardous speculation'.

53 Insolvency Act 1986, sch 4A, s 2 (2), gives as a mitigating factor whether the bankrupt has cooperated with the official receiver.

54 The disqualification of 'undischarged' bankrupts in the Irish Republic, dating from 1923 and in its modern form in the Electoral Act 1992, was removed in 2014. This was a response to an action initiated by a Miss Godsil, herself a bankrupt, who had announced her intention to stand in the European Parliament elections for May 2014. Her action, based on certain provisions of the Constitution, was thereby rendered moot, leaving only procedural matters to be resolved by the Supreme Court: see Godsil v Ireland [2015] IESC 103, [2015] 4 IR 535.

55 Mill (n 8) 282.

56 Representation of the People Act 1918, s 9 (2). 
the same Act denied the vote to those who were in receipt of poor relief 'or other alms' ${ }^{57}$ It was probably not thought necessary to extend the same disqualifications to candidates for Parliament, it being considered inconceivable that persons falling into either category would offer themselves for office or that they would have a realistic chance of being elected even if they were to do so.

The remarkable fact about disqualification for bankruptcy, or conscientious objection to military service, is that the individual concerned (or, in the former case, his creditors) was simply availing himself of a concession granted by the law. This marks them out as entirely different to any form of criminal conduct, and hence as not being appropriate to being subjected to any form of 'punishment'.

\section{Safeguarding Against Financial Corruption}

On principle it might be thought that measures taken in order to prevent corruption in government, notwithstanding their importance, should not find a place in the constitution itself. Constitutions are concerned with the principal institutions of the state, their composition and powers, and their relationships as between themselves and the citizen. Arrangements that seek to assure financial integrity in government should therefore be relegated to the sub-constitutional level. However, matters that touch on financial propriety are sometimes inextricably tied up with wider questions of institutional design. The extent of the possible problem is revealed in the diversity of payments that can be made to those in governmental positions. The three instances to be examined in this section have all been viewed as giving rise to the danger, however remote, of corruption. Certainly, all these forms of payment may be made without the least suspicion of underhand behaviour. However, any type of consideration that is payable to members of the legislature, whether in their role as such or in the capacity as members of the executive, can give rise to the possibility (at least) of the purchase of votes or influence.

\subsection{Offices of Profit}

The long struggle for power between the British Monarch and Parliament had several facets, one of which is especially relevant to the present subject. It took the form of the Monarch appointing MPs to so-called 'offices of profit' under the Crown so as to make them beholden to him. Historically, this was a most significant

57 Representation of the People Act 1918, s 9 (1). 
method whereby royal influence was brought to bear in Parliament. The device was neutralised by the Act of Settlement 1701, which provided that the holding of an office of profit under the Crown disqualified the holder from membership of the House of Commons. Eventually, fears on this account came to be seen as no longer well founded and section 1 (4) of the HCDA 1975 provided that, subject to some exceptions, the holding of 'an office or place of profit under the Crown' - or any other office or place - was no longer to disqualify a person from sitting in the Commons. The reason for this was a significant change in the constitutional landscape in the intervening years: that the survival of ministers in office increasingly came to depend more on support in Parliament and less on royal patronage. Nevertheless the existence of the limitations on the number of salaries that are payable to ministers, stipulated (as already seen) in the Ministerial and other Salaries Act 1975, indicates that the threat of 'purchase' of influence in the legislature by the executive has not been entirely removed. The source of the threat has changed from the Crown to the elected government of the day, which, apart from any question of financial inducement, is in a position to attempt to secure a compliant Parliament by extending the numbers of persons constrained by the obligations of collective responsibility.

The phrase 'office of profit' has been deployed at different times in several constitutions of the English-speaking world. The British North America Act 1867, subsequently renamed as the Constitution Act 1867, in section 83 appeared to use the term as a synonym for a salary, referring to '[...] an annual Salary [...] Emolument, or Profit [...] of any Kind [...]' The Federal Constitution of Malaysia disqualifies a member of either House of Parliament merely if he holds 'an office of profit'. ${ }^{58}$ The Constitution of India goes further in stipulating that the office of profit must be under the government of India or that of any State (unless Parliament legislates to the contrary). ${ }^{59}$ There are even echoes of the same phrase in the constitutions of countries - in particular, Ireland and the USA - that have sought to distance themselves from their historical link with Britain. The Irish Constitution, Article 12.6.3, forbids the President to hold 'any other office or position of emolument.' Article 1, section 9, of the US Constitution prevents a person holding 'any office of profit or trust' under the United States from receiving an office or title from a foreign State without the consent of Congress, and section 3, which sets out the disqualifications that are consequent on impeachment, refers more expansively to 'any office of honour, trust or profit'.

Notwithstanding some uncertainty in the phrase, it was clearly the element of 'profit' that held out the prospect of the purchase of votes. Yet this part of the

$58 \operatorname{Art} 48$ (1) (c).

$59 \operatorname{Art} 102(1)(a)$. 
definition did not necessarily bear any correlation to ordinary linguistic usage, for it has been suggested that the profit in question could be 'purely hypothetical'. ${ }^{60}$ In any case, it is clear that Ministers have long been paid for their services in that capacity. ${ }^{61}$ However, the fiction of payment (if such it was) is carried through to the circuitous method whereby MPs are able to 'resign' their position in Parliament by assuming an office of profit under the Crown. The offices, the stewardship of the Chiltern Hundreds and that of the Manor of Northstead, are in fact sinecures which are converted by the device of granting the office 'together with all wages, fees, and allowances'. The striking fact here is that a device that was designed in order to stultify the influence of the Crown over the House of Commons was adapted in part to furnish a curiously indirect means whereby an MP could be permitted to resign his seat.

\subsection{Government Contracts}

The award of contracts, historically, was a means by which the Crown sought to purchase influence in Parliament. So extensive was the practice that the holding of such a contract came to be viewed as a reason in itself to disqualify an individual from membership of the Commons, and the law was accordingly changed by the House of Commons (Disqualification) Acts of 1782 and 1801. Although these statutes were eventually repealed, by section 9 of the HCDA 1957, they were in force for long enough to be copied into jurisdictions which fell under British sway. Prominent examples are to be found in the constitutions of Australia, ${ }^{62}$ Jordan, $^{63}$ and Malta. ${ }^{64}$

If the aim of the prohibition was to combat the possibility of corruption, it was far too blunt an instrument for this purpose. The negotiation of government contracts came increasingly to be confined to a few leading members of the government whose departmental responsibilities included the conduct of such negotiations - a point that was reflected in a guiding set of principles, limited to

60 JDB Mitchell, Constitutional Law (2nd edn, W Green \& Son 1968) 121.

61 For a historical account see William Farr, On the Pay of Ministers of the Crown, a pamphlet extracted from the Journal of the Statistical Society of London for June 1857.

62 Constitution of Australia, s 44 (iv). The disqualification extends to those holding a pension that is payable during the pleasure of the Crown but is stated not to cover Ministers of the Crown.

63 Constitution of Jordan (revised version, 2011), art 75(2). This disqualifies a member of the Senate or House of Representatives who has a contract with any government department, subject to some exceptions such as contracts for the lease of land.

64 Constitution of Malta, art 54(1)(c). This is subject to a proviso relating to publication of the content of the contract in the Gazette. 
Ministers only, that was issued in 1952 by the Prime Minister, Winston Churchill. ${ }^{65}$ Yet the prohibition in its original form encompassed all MPs, whether government or opposition, front-bench or back-bench. Even its terms will have become outdated as business came to be conducted increasingly through limited companies rather than by sole traders. The most significant change of all has been the considerable formalisation of procedures in public procurement generally as a result of British membership of the EU. ${ }^{66}$ To all these historical changes should be added the point of principle: that it is far preferable to prevent situations of conflict of interest from arising in the first place than to disqualify contractors after the event from sitting in the House of Commons. ${ }^{67}$

\subsection{Emoluments Payable to Members of the Executive and the Legislature}

This heading furnishes an additional comparative perspective on the constitutional arrangements of the UK and the USA, deriving from the partial merger of legislature and executive in the former case and their complete separation in the latter. These facets give rise, in turn, to contrasting issues stemming from the element of payment. Indeed, the payment of emoluments to a person as a legislator and/or as a member of the executive can give rise to problems in those countries where the constitution derives from the Westminster model, but where the circumstances are unlikely to present themselves at Westminster itself. ${ }^{68}$

A brief historical survey must start by noting that originally, far from receiving remuneration, MPs were required to satisfy a property qualification - a rule that

65 HC Deb 25 February 1952, vol 496, col 701.

66 See Sue Arrowsmith, The Law of Public and Utilities Procurement: Regulation in the EU and UK (3rd edn, Sweet \& Maxell 2014).

67 A case in point was that of Liam Byrne, a junior minister at the Home Office, who in 2006 was found to be the owner of a substantial shareholding in a firm that sold computer systems to the police forces. He denied any impropriety since he had taken no part in the procurement process, and was reported as intending to sell the shares.

68 A strikingly unusual case in this vein is Sharma $v$ Attorney-General of Trinidad and Tobago [2007] UKPC 41, [2007] 1 WLR 2223 (PC). Both parties at a general election in Trinidad and Tobago won the same number of seats in the House of Representatives. A Speaker could not be elected since no candidate could secure a majority of votes. This meant that, since there was no one to administer the oath of allegiance, a precondition of the payment of parliamentary salaries was not met. The President nevertheless appointed a Prime Minister, who proceeded to appoint ministers. Members of the government were thus able to draw their ministerial salaries (at least) while others, though willing to take the oath of office, went unpaid. The Judicial Committee of the Privy Council ruled that, in these circumstances, the right to payment took priority. 
was abolished in 1858. When remuneration was finally introduced, in August 1911, the payment ( $£ 400$ a year) was authorised by nothing more than a resolution of the House of Commons and documented merely as an item hidden in a schedule to the Appropriation Act 1911. This is in marked contrast to the present position, when salary changes whether for MPs or Ministers are implemented by Act of Parliament. ${ }^{69}$ The making of payments gave scope for posing, for the first time, some combined questions of private law and constitutional law. Were MPs in an employment relationship: if so, with whom? Were they thereby made subject to the doctrine of vicarious liability? Had their status changed from being self-employed to employed persons, possibly rendering them holders of offices of profit under the Crown ${ }^{70}$

In this matter of emoluments, the US Constitution was in advance of Britain. It made provision at the very outset, in Article I, section 6, for the payment of salaries to members of Congress. This provoked some disagreement at the time on the ground that service in the legislature was an occupation that should be reserved to men of private means. Yet there is a danger that any transfer of money might contain an element of a hidden bribe, especially if the number of persons in receipt of a salary is excessive - a danger against which the Ministerial and other Salaries Act 1975 (considered in Section 4, above) seeks to guard in the case of the executive branch of British government. That which is true of the payment of salaries can also apply to increases in salary. The relevant issues in the USA, with its separation of powers as between the executive and legislative branches, are in this respect somewhat different to those of the UK. Article I, section 6, in accordance with that doctrine, stipulates that a person who is a member of either House of Congress may not hold any civil office under the United States at the same time. This allows, at least, for the possibility of transfer as between the two spheres of government. If it were simply a separation of powers provision, there could be full compliance with it if a Congressman or Senator were to resign in that capacity and proceed then to take up a civil office under the United States. However, section 6 goes on to forbid

69 This has been in the absence of any safeguard like that provided by the Twenty-Seventh Amendment to the US Constitution (1992). This requires the interpolation of an election before a salary increase for members of Congress may take effect, with the result that sitting members may be required to justify the proposed increase to the voters.

70 This point was raised in Martin v O'Sullivan (Inspector of Taxes) [1984] STC 258. Extraordinarily the case was a challenge to the validity of a statute which had increased the rate of National Insurance (a form of taxation) payable by the plaintiff. Not surprisingly, the challenge failed since the same argument, had it been accepted, could also have been deployed to challenge any other statute. 
the appointment of a Senator or a Representative to any civil office under the United States which, during the period for which he was appointed, was created or 'the emoluments whereof shall have been increased during such time'. In this regard the provision goes beyond separation of powers considerations and becomes in some degree an anti-corruption measure. ${ }^{71}$

\section{A Ground of Disqualification for the Nuclear Age?}

At the beginning of the article, the example was given of an age condition: that the US President must have attained the age of 35 years. Remarkably, this provision is not matched by an upper age limit. Yet if there is a risk of immaturity in the youthful holder of public office, in the case of his elderly counterpart there is a danger of, if not senility, at least a precipitate decline in his faculties. The detailed terms of most age qualifications, whether upper or lower, are of necessity somewhat arbitrary and vulnerable to the charge of being discriminatory in nature. Infirmity can afflict the young as well as the old. But, at least, there exists the possibility of an alternative approach to the blunt instrument of an upper age condition. Consequently, it would be suitable to conclude the body of this article by addressing a reason for denying office which has not ranked as a ground for constitutional disqualification: exhibiting signs of severe illness, whether physical or mental. Certainly, constitutions typically make provision for the suspension from office of a person who has already fallen ill. A notable example is the TwentyFifth Amendment to the US Constitution, the terms of which provide for continuity of function in the Presidency. In the UK, in the same way, there exists a procedure for the functions of the Monarch to be discharged by a Regent when he or she is suffering from 'infirmity of mind or body' or is not available for the performance of the duties of the role. ${ }^{72}$ However, of greater significance, especially in the nuclear age, is the need to take steps to prevent the possibility of a person who is afflicted with a severe malady, especially mental illness, from attaining office in the first place. The extent of the problem of ill-health in the highest reaches of government has been documented in a book by Lord Owen (formerly David Owen MP) which

71 As such it has proved of limited value, being capable of circumvention by a device known as the 'Saxbe fix'. The name derives from the original instance of its application, on the appointment in 1973 of Senator William Saxbe to the office of Attorney-General. It took the form of reducing the pay for the office to the level that was applicable at the start of Saxbe's term as a Senator.

72 Regency Act 1937, s 2(1). 
surveys a number of case studies across several jurisdictions. ${ }^{73}$ His conclusion is that illness, of whatever sort, in leading figures in government over the last hundred years has been a significant factor that has led to poor decision making. Yet he holds back from suggesting that it be made a peremptory ground for disqualification from office, urging instead the publication of an independent medical assessment of all candidates who stand, whether directly or indirectly, for the post of head of government.

Occupants of public office who suffer from severe illness can pose a greater threat to the national interest than persons who are barred from such office on any of the grounds of disqualification that have been examined in the present article. Nevertheless there would be many problems in adopting Lord Owen's proposal. Would submitting to the medical assessment be optional, or should it (like the swearing of the oath of office) be a legal precondition of holding office? Should it apply only to the titular head of government, or the political head, or both? Above all, there would be inordinate difficulties in anticipating, and defining in legal terms, the risks that are involved so as to rule out the very possibility of making suspect selections in the first place. Perhaps it is for this reason that, in the absence of a workable machinery of prevention, trust continues to be reposed in all concerned to make a sound choice of their leaders.

\section{Conclusion}

All constitutional systems must address the issue of the possible disqualification of individual voters. The same issue must also be addressed in regard to those who occupy, or are candidates for, political positions. Only the most compelling of reasons for disqualification should be accepted since all such barriers detract from the democratic ideals of universal suffrage and equal access to positions of power. Certainly, some residual compliance with those ideals can, at least, be maintained in the case of disqualifications that relate to elective office and where the rule derives from convention rather than law, thereby leaving the final issue whether to comply or not with the voters themselves. Nevertheless this article has aimed to show that many of the grounds of disqualification that are founded on law and have been inspired by British antecedents are difficult to defend on general principle. They should be critically assessed in favour of other grounds of

73 David Owen, In Sickness and in Power: Illness in Heads of Government during the Last 100 Years (Methuen 2008). Owen was uniquely well qualified to write this account, combining medical training with experience in office as British Foreign Secretary 1977-79. 
disqualification that are more appropriate responses to the hazards of the modern world.

Acknowledgment: For assistance on particular points I am grateful to Richard Albert, Eleanor Aspey, Rodney Brazier, Giuseppe Franco Ferrari, Richard Kilpatrick, David Milman, Laith Nasrawin, and Graham Smith. 